\title{
除水による蛋白濃縮度の意義の検討
}

\author{
田部井 薫 黒田 豊 高 野 隆一 増 永 義 則* \\ 井上 真* 赤井 洋一* 浅 野 泰* \\ 自治医科大学附属大宮医療セン夕一腎臟科 自治医科大学腎臟内科*
}

key words：plasma refilling, 総蛋白濃度, 循環血漿量, 至適透析, ドライウェイト

〈要旨〉

透析中の除水により血圧が低下することがあるが，これは循環血液量の減少によるといわれている．しかし，臨 床的には簡便に循環血液量の変化を知る方法はない. 今回我々は血清総蛋白濃度 (TP) を透析前後で測定し，产の 濃度変化から循環血漿量（CPV； circulating plasma volume）の変化を推定してドライウェイトの設定に役立つか 否かを検討した。

透析中に循環血中の蛋白総量が变化しないとするならば, $C P V_{B} \times T P B=C P P_{A} \times T_{A}$ が成立する. ここでBとAは透 析前と後を表す。したがって, 総蛋白濃度変化 (TPB $/ \mathrm{TP}_{\mathrm{A}}$ ) は循環血漿量の変化 $\left(\mathrm{CPV} \mathrm{A}_{\mathrm{A}} / \mathrm{CPV}_{\mathrm{B}}\right)$ を表す。61例の 安定維持透析患者で, 12〜24 か月にわたり透析前後の総蛋白濃度とその他のパラメーターを比較した.

循環血漿量の変化 $(\% \Delta \mathrm{CPV})$ は体重変化率 $(\% \Delta \mathrm{BW})$ と正の一次相関を示した $(y=3.54 x-0.16, r=0.63, p<$ $0.0001, n=992)$ ） そこで，\% $\mathrm{CPV} / \% \Delta \mathrm{BW}$ (PWI; plasma body weight index) を指標として，5群に分けて検 討した。 | 群 $\mathrm{PWI}<0$, II 群 PWI 0-2, III群 PWI 2-4, IV群 PWI 4-6, V 群 PWI>6，心胸郭比 (CTR) はI, IIで 有意に大きく, 透析による血圧低下はIV, V 群で有意に大きかった. 各個人の PWI と CTR との関係をみると, 観察 期間中に CTR の変化が $5 \%$ 以下の症例では PWI と CTR に相関はないが, $8 \%$ 以上の変動のあった症例では 19 例中 15 例で負の有意な相関を示した。つまり，CTR の増加に伴いPWI は減少した。

以上のことから，透析前後の総蛋白濃度を測定することは有用で，循環血漿量の変化を知ることができる，关の 結果, $1 \%$ の体重変化は循環血漿量を平均 $3.5 \%$ 減少させた. 循環血漿量変化率/体重変化率で定義される PWI はド ライウェイト設定の指標の一つとなりうると思われた.

\section{Significance of total protein concentration by water removal during hemodialysis}

Kaoru Tabei, Yutaka Kuroda, Ryuichi Takano, Yoshinori Masunaga*, Makoto Inoue*, Yoichi Akai*, Yasushi Asano*

Division of Nephrology, Oomiya Medical Center, Jichi Medical School ; Department of Nephrology, Jichi Medical School*

Hypotension is frequently encountered during hemodialysis (HD), which may be due to circulation collapse by water removal. However, in some patients, large fluid removal does not induce hypotension, and in others small fluid removal induces hypotension. Therefore, we examined the vascular permeability in hemodialysis patients (Nephron $74: 266,1996$ ), and found that the vascular permeability varied widely in each patient according to the ANP concentration (Nephron $74: 19,1996)$. This calculation required the use of a computer, thus we devised a simple index to determine the changes in circulating plasma volume (CPV), by measuring the total protein concentration (TP) before and after HD.

Assuming that the total amount of circulating protein does not change during $H D, C P V_{B} \times P_{B}=C P V_{A} \times$ TPA, where $B$ and $A$ denote before and after HD, respectively. Thus TPB/TPA equals $C P P_{A} / C P V_{B}$. In 61 stable maintenance HD patients, TP was measured before and after HD every month for 12 to 24 months. When

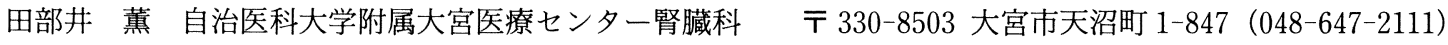

Kaoru Tabei Fax 048-648-6831

〔受付：平成 10 年 4 月 24 日，受理：平成 11 年 2 月 24 日〕 
$\mathrm{CPV}_{\mathrm{A}} / \mathrm{CPV}$ (\% $\% \mathrm{CPV}$ ) was plotted against the changes of body weight during $\mathrm{HD}(\% \Delta \mathrm{BW})$, a linear correlation was observed $(y=3.54 x-0.16, r=0.63, p<0.0001, n=992)$, suggesting that a $1 \%$ change in body weight induces $3.5 \%$ reduction of circulating plasma volume on average.

When we divided all patients into five groups according to the $\% \Delta \mathrm{CPV} / \% \Delta \mathrm{BW}$ as follows : group I, $<0$; II, $0-2 ;$ III, 2-4; IV, 4-6, and V, $>6$, the mean value of CTR was significantly higher in groups I and II compared with the other groups, and the reduction rate of MAP during HD was larger in groups IV and $V$. This finding indicated that in patients with a low $\% \Delta \mathrm{CPV} / \% \Delta \mathrm{BW}$ ratio, the dry weight should be reduced. To confirm this theory, the $\% \Delta \mathrm{CPV} / \% \Delta \mathrm{BW}$ was plotted against CTR. In patients whose CTR changes were less than $5 \%$ for two years, no correlation was revealed between the ratio and CTR. However, in patients whose CTR changes were more than $8 \%$ for two years, 15 out of 19 patients showed a close linear correlation between the ratio and CTR.

In conclusion, the change in TP before and after HD indicated the change in circulating plasma volume during HD. The change in $1 \%$ body weight induced $3.5 \%$ reduction of circulating plasma volume on average, and the $\% \Delta \mathrm{CPV} / \% \Delta \mathrm{BW}$ showed a close correlation with CTR, indicating that this ratio was a useful indicator to determine the hemodynamic change during hemodialysis.

\section{はじめに}

透析患者のドライウェイト (DW) の設定は, 日常臨 床で苦慮するところである. 教科書的には11, 心胸郭比 (CTR) と浮腫, 心不全の有無, 透析中の血圧低下の程 度, 筋痙卛などの理学所見を指標とする.しかし, CTR は心疾患を有する症例では単純に評価することはでき ない，そこで近年，我々は超音波断層法による下大静 脈径を指標とした DW 設定を提唱してきた ${ }^{22}$.さらに, 透析患者において, 透析中の除水と plasma refilling の関係についても検討してきた吕). その研究から, 総 蛋白が透析により著明に濃縮されること, 総蛋白濃度 の変化が循環血槳量の変化を表わすことに着目し, 本 論文では, 透析前後の蛋白濃度変化が DW の設定の一 つの指標となるかどうかについて検討した.

\section{I．対象ならびに方法}

対象は, 関連病院で維持血液透析を受けている慢性 透析患者 86 名で，以下の基準により患者を選択した。 1) 過去 1 年以上にわたり透析前後の総蛋白が測定さ れている，2）透析前後の体重減少量が $0.5 \mathrm{~kg}$ 以上で ある，3） $\mathrm{HDF}, 10 \% \mathrm{NaCl}$ 注入などの特殊透析を 行っていない，その結果，これらの基準に該当した患 者 61 名を解析対象とした.ただし, 選択された症例で, 検査日の透析中に生理食塩水投与を行った場合には, その検査日の成績のみを除外した。

対象患者の総数 61 名の背景は, 男 43 名, 女 18 名, 平均年齢は $51.1 \pm 1.3$ 歳で, 平均透析期間は $9.6 \pm 0.7$ 年, 原疾患は, 慢性系球体腎炎 41 名, 糖尿病 10 名,
腎硬化症 4 名, 多発性囊胞腎 2 名, 悪性高血圧 1 名, Goodpasture 症候群 1 名, 神経因性膀胱 1 名, 腎結核 1名であった。

検討方法：月に 1 回の透析前後の血液検查施行日 に, 総蛋白を測定し, 検査日の透析前後の体重, 血圧 の変化を記録する．さらに，検査日に最も近い CTR を 記録した. 各個人の対象検査回数は, 平均 $15.4 \pm 0.3$ 回 で，検討対象となった透析回数は 992 回であった。

透析にても, 蛋白の言失がないものとすれば, 循環 血中総蛋白量 (TP mass) は,

$\mathrm{TP}$ mass $=\mathrm{CPVB} \times \mathrm{TPB}_{\mathrm{B}}=\mathrm{CPVA} \times \mathrm{TPA} \cdots \cdots \cdots \cdot$ 式 1 と表わすことができる。ここで，CPV は循環血漿量 (circulating plasma volume；L), TP は総蛋白濃度 $(\mathrm{g} / \mathrm{d} l)$, в と A は透析前, 後を表わす。

この式から, $\mathrm{CPV}$ の変化率 $(\% \Delta \mathrm{CPV})$ は, $\% \Delta \mathrm{CPV}=\mathrm{CPVA} / \mathrm{CPVB} \times 100=\mathrm{TPB} / \mathrm{TPA} \times 100$ 式 2

と表わすことができる，つまり, 透析前後の総蛋白濃 度の変化は循環血漿量の変化を表わすことがわかる。

ここで, 近年使用されている蛋白漏出性の透析膜な ぞにより蛋白濃度が変化する可能性もあるが, 仮に 60 $\mathrm{kg}$ の患者でへマトクリット $(\mathrm{Ht})$ が $30 \%$, 総蛋白濃度 が $7 \mathrm{~g} / \mathrm{d} l$, 循環血液量が体重の. $7.7 \%$ とすると, 循環血 液量は $4620 \mathrm{~m} l$, 循環血漿量は $3234 \mathrm{~m} l$, 従って循環血 中総蛋白は $226.4 \mathrm{~g}$ である. 透析により $5 \mathrm{~g}$ の蛋白が 失われたとしても蛋白濃度は $2.2 \%$, つまり $0.15 \mathrm{~g} / \mathrm{d} l$ しか低下しないことになる。この濃度変化はほぼ測定 誤差範囲と考えてょく，今回の計算に大きな支障はな いと考えられる.

さらにこのことを確認するために, 透析前後で総蛋 白と Ht を同時に測定し, Ht の変化から計算した透析 


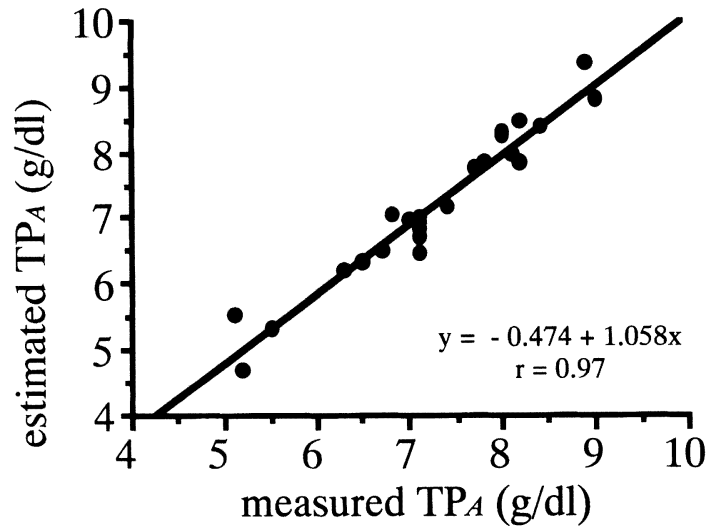

図 1 Relationship between measured TPA and estimated TPA by the changes in hematocrit. To confirm that protein loss did not play a significant role to estimate the change of circulating plasma volume by the change of protein concentration, the relationship between total protein and hematocrit were examined.

TPA could be calculated by the value of $\mathrm{Ht}$ by the following equation, estimated TPA

$=\mathrm{TPB} \times \mathrm{HtB} / \mathrm{HtA} \times(1-\mathrm{Hta} / 100) /(1-\mathrm{HtB} / 100)$

When measured TPA was plotted aginst estimated TPA calculated by the changes in $\mathrm{Ht}$, there was a close linear correlation $(\mathrm{y}=-0.474+1.058 \mathrm{x}, \mathrm{r}=0.97, \mathrm{p}<0.0001)$, suggesting protein loss during hemodialysis did not play a significant role to estimate the change of circulating plasma volume by the change of protein concentration.

後総蛋白推定値と実測値を比較した.

透析中に循環血中の血球容積が変化しないとすれ ば,

$\mathrm{CBVB} \times \mathrm{HtB} / 100=\mathrm{CBVA} \times \mathrm{HtA} / 100$ 式 3

が成立する。ここで， $\mathrm{CBV}$ は循環血液量 (circulating blood volume；L)を表わす。一方, 循環血漿量 (CPV) を循環血液量（CBV）を用いて表わすと，

$\mathrm{CPVB}=\mathrm{CBVB} \times\left(1-\mathrm{Ht}_{\mathrm{B}} / 100\right) \cdots \cdots \cdots \cdots \cdots \cdots \cdots \cdot$ 式 4

$\mathrm{CPVA}=\mathrm{CBVA} \times\left(1-\mathrm{Ht}_{\mathrm{A}} / 100\right)$

と表わすことができる。これらの式 $2 ， 3 ， 4 ， 5$ から， 透析前の総蛋白濃度 (TPB), Ht の変化から透析後総 蛋白濃度（TPA）を計算する式は,

推定 TPA $=\mathrm{TPB} \times \mathrm{HtB} / \mathrm{HtA} \times(1-\mathrm{HtA} / 100) /(1-\mathrm{HtB} / 100)$ .式 6

透析前後の体重変化率 $(\% \Delta \mathrm{BW})$ は以下の式にて求 めた.

$\% \Delta \mathrm{BW}=(\mathrm{BWB}-\mathrm{BWA}) / \mathrm{BWB} \times 100$ ·式 7

透析中の平均血圧の変化は, 透析回路をつないで除

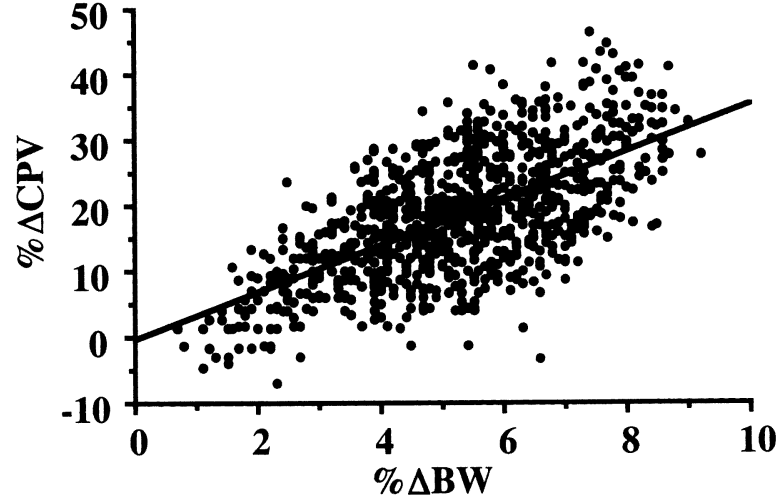

図 2 Relationship between $\% \Delta B W$ and \% $\triangle \mathrm{CPV}$. When $\mathrm{CPVA} / \mathrm{CPVB}(\% \Delta \mathrm{CPV})$ was plotted against the changes of body weight during $\mathrm{HD}(\% \Delta \mathrm{BW})$, they showed a linear correlation $(y=3.54 \mathrm{x}-$ $0.16, \mathrm{r}=0.63, \mathrm{p}<0.0001, \mathrm{n}=992)$. This figure indicated that the change in $1 \%$ body weight induced $3.5 \%$ reduction of circulating plasma volume as a mean, when TP before HD was $6.6 \pm 0.1 \mathrm{~g} / \mathrm{d} l$ and TP after HD was $8.2 \pm 0.1$, was BW before HD was $56.7 \pm 1.1 \mathrm{~kg}$ and after HD 53.7 \pm 1.1 , thus BW reduction was $3.0 \pm 0.1 \mathrm{~kg}$ and $\% \Delta \mathrm{BW}$ was $5.3 \pm 0.2 \%$.

水を開始する直前の血圧と除水終了直前の血圧より求 めた。

統計処理は, 直線回㷌, student $t$ test, 重回㷌分析 を用いた３群以上の比較は分散分析（analysis of variance）検定を行い，各群間の有意差検定には Fisher 検定を用いた. $\mathrm{p}<0.05$ を有意差ありとした.

\section{II. 結 果}

まず，透析による蛋白の漏出が透析後蛋白濃度変化 に与える影響を検討したが, Ht の変化より推定した TPA と実測 TPA の関係は, $\mathrm{y}=0.473+1.06 \mathrm{x} \quad(\mathrm{n}=$ $22, \mathrm{r}=0.970, \mathrm{p}<0.0001)$ と極めて密な正の一次相関 を示した(図 1)。このことから，透析による蛋白の漏 出が透析後蛋白濃度変化に与える影響は極めて少ない ことがわかる。

次に, 全症例での検査結果をみると, 透析前後の総 蛋白濃度は, $6.6 \pm 0.1,8.2 \pm 0.1 \mathrm{~g} / \mathrm{d} l$ で, 体重は透析 前 $56.7 \pm 1.1 \mathrm{~kg}$, 透析後 $53.7 \pm 1.1 \mathrm{~kg}$, 除水量は平均 $3.0 \pm 0.1 \mathrm{~kg}$, 体重減少率は平均 $5.3 \pm 0.2 \%$, 平均 CTR は 47.8土0.4\%, 平均血圧は収縮期 $151.7 \pm 1.9$, 拡張期 $84.9 \pm 0.9 \mathrm{mmHg}$ であった.

そこで透析前体重に対する体重減少率 $(\% \Delta \mathrm{BW})$ と 蛋白濃度変化より計算した循環血漿量変化率（\% $\Delta \mathrm{CPV})$ の関係を検討すると, $\mathrm{y}=3.54 \mathrm{x}-0.16$ と正の 

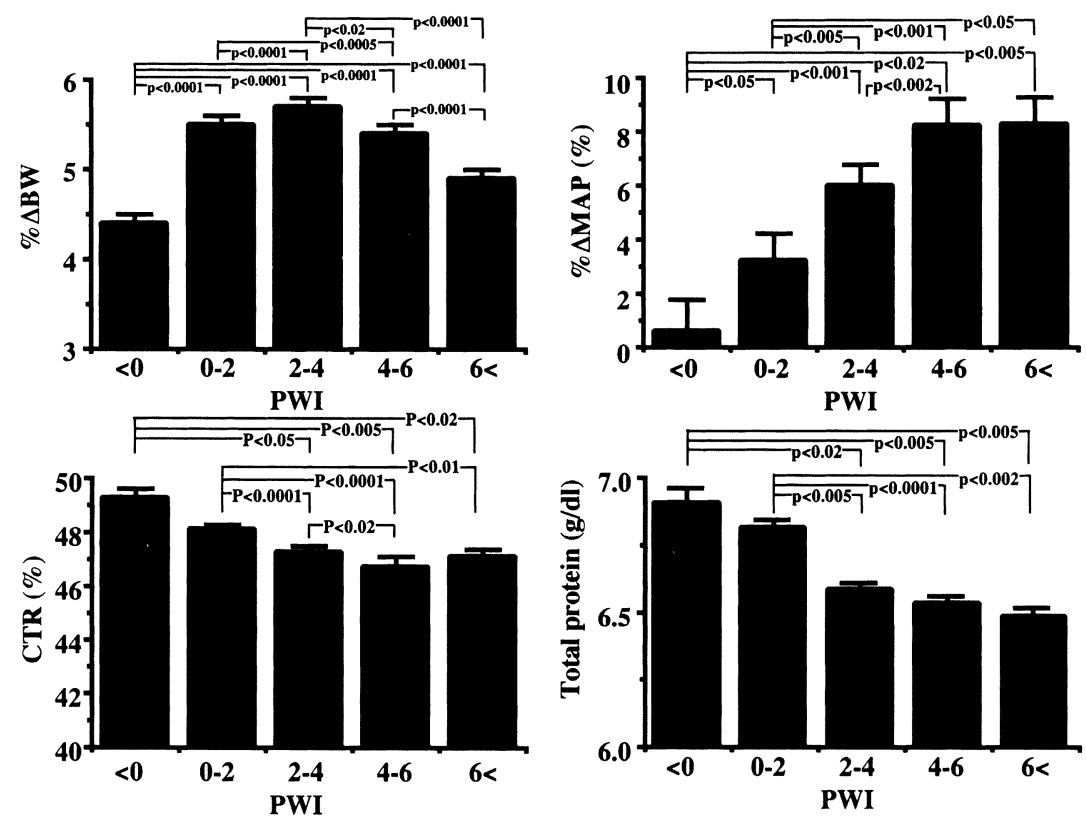

図 3 Parameters in each group. We divided patients into 5 groups according to the ratio of $\% \Delta \mathrm{CPV} / \% \Delta \mathrm{BW}$ (PWI; plasma volume body weigh index), G- I $<0$; G-II $0-2$; G-III $2-4$; G-IV 4-6 ; and G-V $>$ 6 . Although the changes in body weight was the same magnitude, in G-IV and V, blood pressure decreased significantly after hemodialysis and CTR was significantly larger in G- I and G-II. This finding indicated that in patients with low PWI ratio, DW should be down.

一次相関を示した $(\mathrm{n}=992, \mathrm{r}=0.63, \mathrm{p}<0.0001)$ （図 2 ). この図は, 平均でみると体重 $1 \%$ の除水で, 循環 血漿量が $3.5 \%$ 減少することを表わしている.

しかし，図からも明らかなように，同じ体重減少率 でも, 循環血液量の変化率は大きく異なる。そこで, 各個人の体重変化率に対する循環血漿量変化率の比率 $(\% \Delta \mathrm{CPV} / \% \Delta \mathrm{BW}$; 我々はこれを PWI：plasma body weight index と名付けた) を求め, その比率に よる症例の違いを検討した。 PWI が 0 以下の群（ I 群), 0〜2 (II群), 2〜4 (III群) 4〜6 (IV群), 6 以上 ( V群)の 5 群に分け, それぞれの群での除水量, 透析 前総蛋白濃度, 平均血圧の変化, CTR などを検討した (図 3 )。その結果，1）体重変化率 $(\% \Delta B \mathrm{BW})$ は群間 で有意差があり, I 群, V群で有意に少なかったが, 各群とも 4.5 から $5.5 \%$ 範囲であった．2）透析前 後の平均血圧の変化率 $(\% \Delta \mathrm{MAP})$ は, I 群から V 群 にかけて変化率が有意に大きくなった，3）透析後に 測定した CTR は I 群で有意に大きく, IV, V群で小さ い. また, 透析前総蛋白濃度は, I 群で有意に高く,

V群で有意に少ない.これらのことから, PWI が大き いほど心胸比は小さく, 透析中の血圧変動も大きく DW に近いかあるいは DW が厳しすぎる可能性があ ることが示唆された。
そこで, 個人の 2 年間での PWI の変化と CTR の関 係を検討した. その結果, 図 4 のように CTRの変化と PWI に相関のない群 $(\mathrm{p}>0.10)$ が 34 例, 弱いが相関 $(0.10<\mathrm{p}<0.05)$ を示すものが 7 例, 図 5 のように有 意な相関（ $\mathrm{p}<0.05 ） を$ をすものが 20 例であった.

相関を示さない群での CTR 変動は平均 $5.76 \pm$ $0.36 \% （ \mathrm{n}=34 ）$ で，有意な相関を示す群では 7.97士 $0.53 \%$ で, 有意にCTRの変動が大きかった（p< 0.0001). CTR 変動が $8 \%$ 以上の症例では 19 例中 15 例で有意相関を示した。このことは，観察期間中に CTR の変動が少ないことは DW があまり変化しない ことを意味し, このような症例では PWI が変化する ことは少ないため, 相関関係は得られない. 逆にCTR 変動が大きく DW が大きく変化する症例では PWI が その CTR と逆相関を示すこと.を意味している．この ことを確認するために, 観察期間中の CTR の変動幅 と個々の症例の相関係数, 危険率との回帰を検討する とどちらも $\mathrm{p}<0.0001$ 以上の相関を示した．つまり， CTR 変動が大きいほど CTR と PWI の相関がでやす いことを意味していた.

最後に, PWI をどの程度に設定すればよいかを検討 する目的で，全症例の CTR が 45〜 50\%での PWIを 求めたところ, $3.5 \pm 1.5$ であった. 

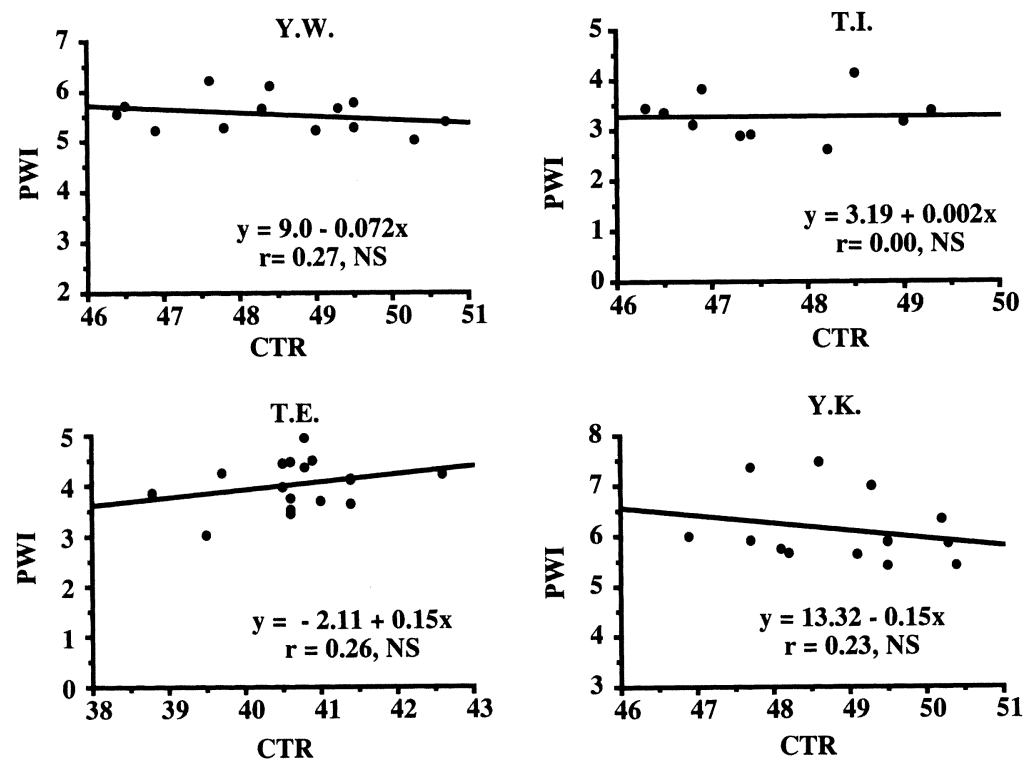

図 4 Relationship between PWI and CTR in patients with small changes of CTR. To confirm the thesis that PWI was useful to determine the DW, PWI was plotted against CTR in all patients. In 34 of 61 patients $(56 \%)$, there were no correlation between PWI and CTR $(\mathrm{p}>0.10)$.
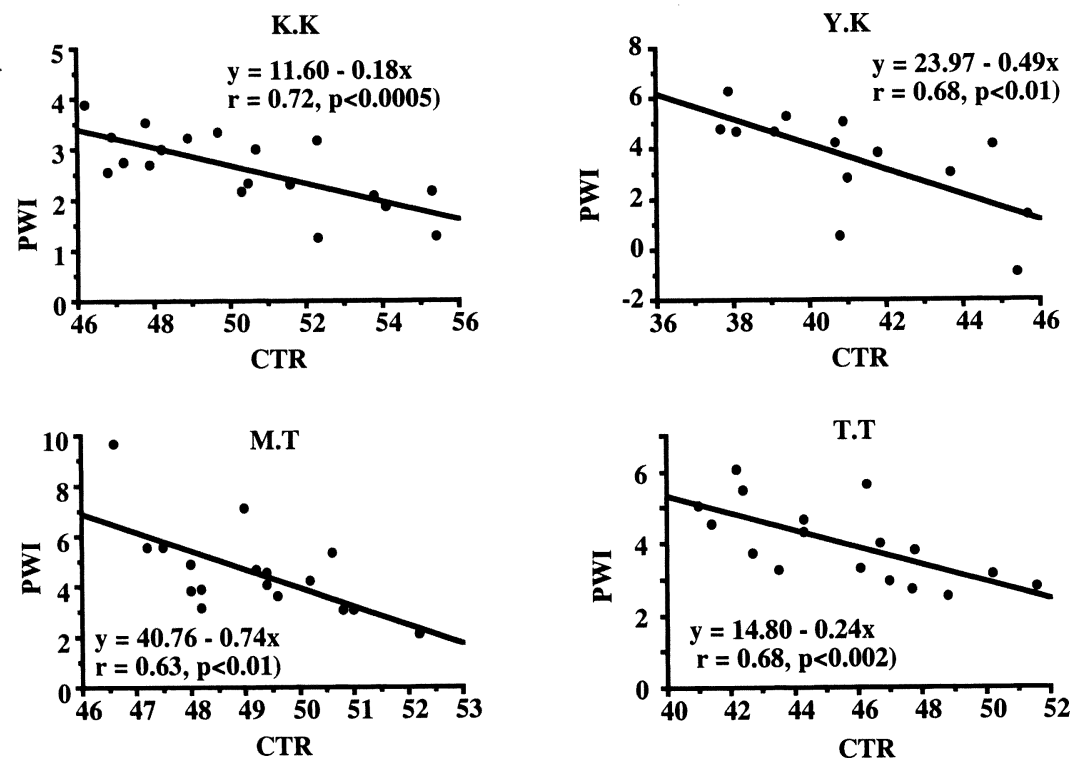

図 5 Relationship between PWI and CTR in patients with large changes of CTR. In 20 of 61 patients (33\%), PWI showed a negative linear correlation with CTR.

\section{III. 考 察}

透析患者では, 1 回の透析にて大量の除水を行うが, 大量の除水を行っても血圧が変化しない例もあれば, 少量の除水にてもすぐに血圧が低下してしまう例もあ る。時に除水が循環血漿量をはるかに越えることがあ るが，にもかかわらず循環血漿量がある程度保たれる のは血管外から水分が移動するためである。そこで
我々は, 透析患者の plasma refilling の指標として plasma refilling index $(\mathrm{Kr})$ の計算式を開発した ${ }^{3)}$. $\mathrm{Kr}$ は, ヘマトクリット, 総蛋白濃度の変動と除水量よ り循環血液量の変化を計算し, さらに水を血管内に引 き込む推進力としての膠質浸透圧の変化を計算して $\mathrm{Kr}$ を求めた。つまり, 広い意味で $\mathrm{Kr}$ は血管透過性を 表わすと考えられる。 その結果, 透析患者では透析初 期には Kr は大きく, plasma refilling が起こりやすい が, 除水につれて Kr は低下し, plasma refilling が起 
こりにくくなる。ささらに, 透析初期の $\mathrm{Kr}$ が高い症例で は除水にても血圧の変動が少ないが, $\mathrm{Kr}$ が初期より低 い症例では血圧が低下しやすい ${ }^{33}$. その後の検討では, Kr は ANP と相関すること ${ }^{4)}, \mathrm{ECUM}$ と HD では, 除 水速度が同程度ならば $\mathrm{Kr}$ に差はないこと年，noradrenalin の注入にても $\mathrm{Kr}$ は変化しないこと帛, $\mathrm{DM}$ と CGN では同程度の除水量では $\mathrm{Kr}$ に大きな差はない が, Kr に比し ANP が高值であることなどを明らかに してきた. Kr の計算にへマトクリット, 総蛋白の透析 中の変化を用いたが，その臨床的意義は大きいものと 考えられた。しかし，Kr は計算が複雑で，一般透析施 設での利用には限界があると考え，より簡便な指標を 検討してきた，そこで，透析前後の総蛋白濃縮に注目 し，今回の検討を行った，総蛋白濃縮には，大きく二 つの意義がある，一つは，膜を介する水輸送に際し， 総蛋白は，膠質浸透圧として重要である。

一般に水の移動は, 能動輸送がない場合には,

$$
\mathrm{Jv}=\mathrm{Lp}[(\pi \mathrm{c}-\pi \mathrm{I})-(\mathrm{Pc}-\mathrm{PI})]
$$

として表わされる。ここで，Jv は膜を介する水の輸送 量 $(\mathrm{ml} / \mathrm{min}), \quad \mathrm{Lp}$ は水透過性 $(\mathrm{ml} / \mathrm{min} / \mathrm{mmHg}), \pi \mathrm{C}$, $\pi \mathrm{I}$ は膠質浸透圧 $(\mathrm{mmHg}), P \mathrm{Pc}, \mathrm{PI}$ は静水圧 $(\mathrm{mmHg})$ を表わす， $\mathrm{C}$ は血管内， I は間質を表わす. $\mathrm{Kr}$ の計算に 際しては，透析患者において透析中の除水速度 (UF) を一定とし，血管内外の水の出入りは，膠質浸透圧差 $(\pi \mathrm{C}-\pi \mathrm{I})$ と静水圧差（Pc-PI）のみにて決定される と想定した。

膠質浸透圧 $\pi \mathrm{C}$ は文献より, 総蛋白濃度を $\mathrm{TP}(\mathrm{g})$ $\mathrm{d} l)$ とすると党,

$$
\pi \mathrm{C}=2.1 \mathrm{TP}+0.16 \mathrm{TP}^{2}+0.009 \mathrm{TP}^{3}
$$

として求められる。 つまり，蛋白濃縮が起こるという ことは，血管外から血管内へ水を引き込もうとする力 が増加することを表し, plasma refilling を促進する方 向へ働く

もう一つの蛋白濃縮の意味は，除水により循環血獎 量が減少する程度を表わしている，今回の検討では， 体重 $1 \%$ の除水が $3.5 \%$ の血漿量の減少に相当するこ とが明らかとなったが,このことは, 体重 $60 \mathrm{~kg}$ の患者 で $\mathrm{Ht}$ が $30 \%$ とするならば，循環血液量が体重の $7.7 \%$ として循環血漿量は $3234 \mathrm{~m} l$, 除水量は $1 \%$ で $600 \mathrm{~m} l$, 循環血漿量 $3.5 \%$ の減少は $113 \mathrm{~m} l$, つまり 487 $\mathrm{m} l$ で除水量の $82 \%$ が血管外から再充填されているこ とになる。ちなみに，上記のような症例で，PWI (plasma body weight index; \% $\mathrm{CPV} / \% \Delta \mathrm{BW}$ ) が 0 とは，除水をしても循環血獎量が変化しないことを 表わし, PWI=2では, plasma refilling rateは

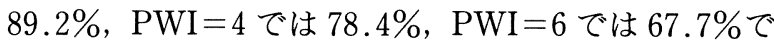

ある。この再充填の程度は個人により異なるのみでな く，心胸比によって変動することを図 5 で検討した. 透析前後の総蛋白の測定は，安価であるため，毎月 測定してもそれほどの経済的負担にはならず，経時的 に測定することにより DW 設定の指標として有用と 考えられる。しかし現在のところ PWIをいくつに設 定すればよいかについては，理論的根拠がないため結 論を出すことはできない，あえて設定すれば，全症例 を対象として CTR が $45 \%$ 以上で $50 \%$ 未満での PWI を計算すると $3.5 \pm 1.5$ (SD) であったことから， 2.0 から 5.0 という設定が妥当と考えたい。しかし，この 数值は経験的数值として理解してもらいたい.さらに, 各透析施設で使用するコンソール, 透析液中 $\mathrm{Na}$ 濃度, 透析液の種類などにより PWI の適正值が異なる可能 性もあり，各々の施設で適正值を設定する必要がある かもしれない.

\section{まとめ}

1．透析前後の総蛋白濃度変化は，循環血槳量の変 化を表わす。

2. 体重変化率 $(\% \Delta \mathrm{BW})$ と循環血漿量変化率 $(\%$ $\Delta \mathrm{CPV})$ の比率 (PWI) は, ドライウェイトの変化に より変動する. 今回の検討からは, $1 \%$ の体重変化で循 環血漿量の $2.0 \sim 5.0 \%$ 減少が妥当である可能性が示 唆された

3. 透析前後採血時総蛋白濃度を測定することは, ドライウェイトの設定の指標の一つとして用いること ができると考えられた。

謝辞：本研究で解析した症例は, 桃李会小山クリニック の患者の成績を使わせていただいた，小山クリニックの看 護婦，技師のご協力に謝意を表したい.

本研究の一部は, 第 41 回日本透析医学会総会および第 14 回国際腎臟学会において発表した。

\section{文献}

1) Lins LE, Hedenborg G, Jacobson SH, Samuelson $K$, Tedner B, Zetterholm UB, Ljungqvist $\mathrm{O}$ : Blood pressure reduction during hemodialysis correlates to intradialytic changes in plasma volume. Clin Nephrol $37: 308-313$, 1992

2) 安藤康宏, 田部井薰, 椎名 明, 浅野 泰, 細田瑳一： 超音波断層法による血液透析中の下大静脈内径変化の 検討一特に除水量との関係について一. 透析会誌 18 ： 173-179, 1985

3) Tabei K, Nagashima H, Iimura $O$, Sakurai $T$, 
Asano Y:An index of plasma refilling in hemodialysis patients. Nephron $74: 266-274,1996$

4) Iimura $O$, Tabei $K$, Nagashima $H$, Asano $Y: A$ study of regulating factors of plasma refilling during hemodialysis. Nephron $74: 19-25,1996$

5) Tabei K, Sakurai T, Furuya H, Muto S, Kusano E, Asano Y: Changes of water permeability coefficient (Lpp) in hemodialysis and extracorporeal ultrafiltration method (ECUM). J Am Soc Nephrol
$4: 424,1993$

6) Tabei $K$, Sakurai $T$, Iimura $O$, Asano $Y$ : Effect of Noradrenaline (NA) on water permeability coefficient (Lpp) in hemodialysis (HD) patients. J Am Soc Nephrol (Abstract) $5: 529,1994$

7) Landis EM, Pappenheimer JR : Exchange of substances through capillary walls. Circulation $2: 961^{-}$ 1034, 1963 